JBT, Volume-XI, No-01\& 02, January-December, 2016

\title{
Myanmar as an Investment Destination: A Regional Evaluation
}

\author{
ABU YOUSUF MD. ABDULlaH
}

\begin{abstract}
Once considered a pariah state because of its military regime, Myanmar has been taking giant strides towards becoming one of the most promising countries for investing in business ventures. At a time when the global economic scenario is reeling from Britain's exit from the European Union, foreign investment in Myanmar continues to attain unprecedented growth. Lifting of international sanctions, a promising economic outlook with a GDP growth rate averaging close to $8 \%$ and a sizeable labor force have attracted overseas investment in diverse sectors like energy, manufacturing, power generation, and construction. The country still faces formidable challenges in developing basic infrastructure, ensuring fiscal stability and curbing sectarian conflict. For the nascent democratic government, formulating and implementing effective policies are uphill tasks in a system fraught with bureaucratic inefficiencies, systemic corruption, and interference from the still-powerful military. Myanmar has ample opportunities to overcome internal roadblocks by utilizing its huge market with a predominantly young population, its expansive pool of low-cost labor and the heightened influx of international commercial ventures after the political transition of the mid2010s. Investments in Myanmar's promising telecommunications sector, in ready-made garment manufacturing and in the tourism industry are projected to give substantial dividends over the next few decades.
\end{abstract}

Key words: Myanmar, Investment, Sanctions, GDP, Global, Regional

\section{INTRODUCTION}

In 2016, an UNCTAD business survey placed Myanmar in $14^{\text {th }}$ position in a global list entitled "MNEs' (Multinational Enterprises) Top Prospective Host Economies for 2016-2018". Since the elections in November 2015, Myanmar has been in the international spotlight as it strides forward amidst multiple

\footnotetext{
*Vice-Chancellor, Northern University of Business \& Technology Khulna (NUBTK), Bangladesh
} 
challenges to take its place as one of the most promising economies of the decade. After 53 years of repressive and mostly inept military rule, the country could breathe in the refreshing air of democracy after the ruling National League for Democracy (NLD) came to power. A renewed sense of hope, coupled with a resurgent economy, has lifted the spirits of the country's mostly impoverished citizens and renewed hope in the world community for the emergence of a prospering Myanmar. Myanmar today is faced with massive challenges like ethnic conflict and illicit trade on one hand and immense opportunities for growth on the other. In this backdrop, it is yet to be seen whether Myanmar manages to transform itself into the next Asian tiger or reverts to being the underdeveloped hinterland of Southeast Asia.

\section{OBJECTIVES}

1. To assess the current macroeconomic scenario of Myanmar and extrapolate its future potential as an emerging market

2. To conduct an analysis on the attractiveness of Myanmar as an investment destination based on factors influencing FDI (Foreign Direct Investment) inflow

3. To gain a comparative understanding of conditions for investing in Myanmar in a regional context

4. To delineate the effects of the historic political transition in Myanmar on the country's investment climate

5. To explore high-potential sectors for foreign direct investment or joint ventures in the upcoming decade 


\section{METHODOLOGY}

Based on inductive reasoning and insights gleaned from historical data, this study takes a data-centric approach to evaluating issues deemed pertinent to the objectives at hand. In order to comprehensively include the aspects required for a succinct perspective of the issue, this study takes seven key factors to be significantly associated with FDI inflows s. $^{\mathrm{i}}$

1. Market size and potential

2. Institutional and regulatory quality

3. Trade openness

4. Infrastructure quality

5. Economic and political stability

6. Labor quality and costs

7. Cultural links

An assessment of Myanmar's attractiveness as an FDI destination has been made on the basis of seven factors, with special emphasis on recent developments in the years of 2015-2016.

Some promising sectors for foreign investment have been identified in tandem with the findings presented in this paper. Insights gleaned from the

overall analysis were also instrumental in formulating the guidelines as to the most promising sectors for investor engagement in the post-2016 Myanmar.

\subsection{Data Collection}

Evaluation of macroeconomic scenario, discussion of the seven factors associated with FDI inflow and identification of prospective sectors for investment - all were done based on the primary and secondary information collected for this study. Primary technique involved questionnaire survey using purposive sampling where in-depth interviews of prospective exporters and policy experts were undertaken. Secondary study involved the thorough study of extant literature in reference to the results of various surveys, development indicators, trade databases and news reports.

Secondary information has been procured from reliable and updated sources of data. Major sources were databases maintained and reports prepared by the World Bank group, various international trade bodies, international consultancy firms and trade bodies of the United Nations. Facts and figures from websites of various ministries and investment authorities of Myanmar, national censuses commissioned by the government and surveys conducted by foreign trade 
chambers provided key insights that were incorporated in this research. Selected news agencies and daily and weekly newspapers' online editions were sources of updated data. Trade statistics from export directories and multidisciplinary articles published in reputed journals consolidated the data collection process.

\section{LIMITATIONS OF THE STUDY}

The insular nature of Myanmar during its long period of military rule and the long-running conflicts in the country's hinterlands created a vacuum in terms of macro-level economic and demographic data. Moreover, secretive government policy resulted in not only inaccessibility of data but also doubts regarding accuracy of official statistics - a phenomena that posed challenges to the authenticity of open data regarding Myanmar. In order to mitigate the effects of skewed statistics on the reliability of this study, data sourcing was diversified to include as many sources as possible.

Another limitation of this study lies in the high level of variability associated with macro-level forecasts - in particular, uncertainties in the nature of long-term extrapolations of socio-political events and economic variables. As numerous studies and real-life instances demonstrate, the accuracy of predictions dealing with factors ranging from GDP growth rate to the outcome of a Presidential election can be significantly skewed. The sheer unpredictability of unforeseen developments, in almost any set of circumstances over a broad timeframe, renders errors in prediction inevitable. Hence, a number of long-term forecasts included in this study, though based on recognized sources like UN trade bodies, ought to be considered to be approximations. ${ }^{\text {ii }}$

\section{MACROECONOMIC SCENARIO AND FDI TRENDS}

In the pre-2017 world economic outlook, expectations for short term FDI prospects throughout the globe have been best described as cautiously pessimistic. ${ }^{\text {iii }}$ For the period of 2016-18, FDI has been projected to decline in both developing and developed countries. The United Kingdom's decision to leave the EU further amplified uncertainty on FDI flows. FDI inflows to Asia were expected to decline in 2016 by about 15 per cent due to the global and regional economic slowdown.

After two years of strong economic growth and macroeconomic stability, Myanmar faced a more difficult economic environment in the fiscal year 20152016. Economic growth declined, but remained strong, at 7 percent during the period, compared with 8.5 percent in 2014-2015. . $^{\text {iv }}$ 
Agricultural output picked up in fiscal year 2014/2015 after two years of sluggish growth, whereas manufacturing and industrial outputs, particularly gas, have also been strong.

Announced greenfield projects in Myanmar totaled \$11 billion in 2015 and $\$ 2$ billion in the first quarter of 2016, pointing to sustained FDI inflows in the near future ${ }^{\mathrm{v}}$. The McKinsey Global Institute expects the total amount of inward FDI between 2010 and 2030 to reach up to a total of $\$ 100$ billion, while increasing investment is expected in infrastructure, labor-intensive manufacturing and extractive industries. For instance, a combination of three projects undertaken by the Electricity Generating Authority of Thailand, involving fossil fuels and hydroelectric power, has an estimated capital expenditure of $\$ 3,326$ million.

The opening up of Myanmar's economy has attracted foreign investments in manufacturing, a sector that accounted for two-thirds of the number of newly approved FDI projects in 2014/15. A large share of these foreign investments was in the garments and footwear sectors, since Myanmar provided an alternative to investors who were looking to diversify from increasingly higher cost locations in China, Vietnam, and Indonesia.

Government statistics put forth the figure of $\$ 9.4$ billion as the amount of foreign direct in Myanmar during the fiscal year that ended in March 2016. The FDI inflow in $2014 / 15$ was $\$ 8$ billion, compared to $\$ 4.1$ billion in 2013/14. Singapore, which put $\$ 4.3$ billion into 55 projects, topped the list of foreign investors for that time period. However, these figures do not reflect the actual amount of investment but rather the amount of investment pledged by firms given approval by the DICA (Directorate of Investment and Company Administration). ${ }^{\mathrm{vi}}$ 
FIGURE 1

AMOUNT OF FOREIGN INVESTMENT BY SECTOR 2015-16

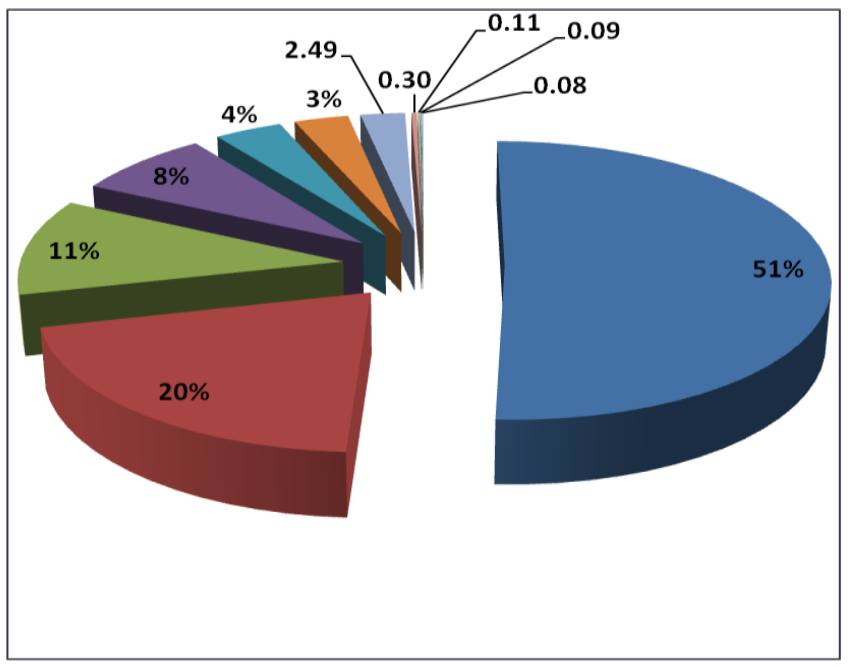

\begin{tabular}{|l|} 
— Oil and Gas \\
$\square$ Transport \& Communication \\
- Real Estate \\
$\square$ Power \\
$\square$ Hotel and Tourism \\
$\square$ Other Services \\
$\square$ Mining \\
$\square$ Industrial Estate \\
$\square$ Livestock \& Fisheries
\end{tabular}

\section{MYANMAR INVESTMENT ATTRACTIVENESS REPORT CARD}

Myanmar, said to be "poised for the next stage of development" vii , has undergone significant transformations in the fields of governance and freedom of speech since the dismantling of five decades of dictatorship. However, issues like lack of energy and transport infrastructure, weakness in policymaking, and political instability continue to plague the country's prospects as the next big investment destination.

\subsection{Market size and potential}

According to the census of May 2015, Myanmar's total population was reported at 51.5 million. The current population is estimated at 56.9 million as of June 2016. ${ }^{\text {viii }}$ With a decelerating population growth rate of $0.89 \%$ per year, the average number of children per woman has declined to 2.3 from 4.7 in 1983 .

In 2015, almost $51 \%$ of Myanmar's overall population was below the age of 27 , though previous years' statistics show this youth bulge to be declining over the decades. People aged 5-9 (5.0 million) and 10-14 (5.3 million) provide opportunities for a possible "demographic dividend".

Among the population age between 15-64 years, participation in the labor force is $67 \%$. Males constitute a significantly higher proportion of the work force with $85.5 \%$ of adult males in the workforce, compared to a $50.5 \%$ labor 
participation rate of females. Unemployment is $4 \%$ and nearly twice as high for those aged 15-29.

Myanmar is regarded as one of the markets with highest potential for growth in the next century. By 2050, its working age population is projected to reach 43 million - a figure even larger than Canada's entire population in 2016.

A study by Mckinsey highlighted the following projections for Myanmar in next two decades: ${ }^{\text {ix }}$

- 28 cities would reach a population of 200,000 or more by 2030 . The sum of their populations would be 19.7 million. The current urban population (2016) is around 8 million.

- The total supply of workers is projected to reach 38 million by 2030 , of whom four million are high-skilled workers, eight million are semiskilled, and the remaining 26 million are unskilled.

\subsection{Institutional and regulatory quality}

Policymaking for the NLD Government: An Uphill Task

On 29 July 2016, the NLD government launched a 12-point economic policy outlining the country's new agenda on business and economics. Prioritizing labor-intensive enterprises was one of the focal points of the government's approach to facilitating economic growth. The long-awaited policy brief highlighted the priority areas for development and the government's vision for the future but was devoid of specific strategies and financial targets. The lack of implementation points was a disappointment for those hoping for more insight regarding the government's plans on promoting business and boosting the economy.

Ease of Starting a Business

According to data collected by Doing Business, the formal process for starting a business in Myanmar requires 11 procedures, takes 13 days, and costs $97.10 \%$ of income per capita. The government has made starting a business easier by eliminating the minimum capital requirement for local companies and streamlining incorporation procedures. ${ }^{x}$ The most recent legislations regarding investment are geared towards paving the way for speedier investment approvals - a development that promises to streamline the usually lengthy procedures required prior to starting business ventures in the country. 
Investment-Related Legislation

For foreign investors, the rules of the game differ for investments outside and within Special Economic Zones (SEZs). The Myanmar Special Economic Zone Law, ratified in 2014, is applicable for new investments in the designated SEZs only. ${ }^{\mathrm{xi}}$

For investments outside SEZs, the country's new Investment Law will come into force for the financial year starting April 2017. While the exact contents of the new law have yet to be finalized, many of its key features have already come to the surface. The Investment Law combines the previous Myanmar Citizen's Investment Law with the Foreign Investment Law, ending Myanmar's status as the only ASEAN member with separate investment laws for local citizens and foreigners. ${ }^{\text {xii }}$ Moreover, it is expected that the new law will repeal some archaic provisions that barred complete foreign ownership in many sectors including agriculture and tourism.

\section{Tax Scenario}

Before the most recent amendments in the law, Myanmar had made paying taxes less costly for companies by reducing the corporate income tax rate in 2014. However, in 2015, Myanmar made paying taxes more costly and complicated for companies by increasing the rate paid by employers and ceiling for social security contributions and by adding more paperwork in the payment procedures.

Legal System

In 2016, Myanmar enacted a new arbitration law, providing a comprehensive legal framework for the conduct of domestic and international arbitration. The legal system of Myanmar has a negative reputation for decades of unethical practices and widespread lack of transparency. A lack of trust in the judiciary stems from a combination of widespread corruption and endemic nepotism in a country still haunted by the shadow of military dominion. 


\section{Utility Connections and Supply}

The Myanmar government's Ministry of Electric Power enacted some measures to reduce delays in providing new electricity connections by decreasing paperwork over the past few years. However, the fragile state of the national power grid means that power cuts are fairly commonplace, while many states and regions are yet to be connected in the central power network.

TABLE 1 TIME REQUIRED TO GET ELECTRICITY (DAYS) ${ }^{\text {xiii }}$

\begin{tabular}{|l|l|l|l|}
\hline Country & $\mathbf{2 0 1 3}$ & $\mathbf{2 0 1 4}$ & $\mathbf{2 0 1 5}$ \\
\hline Myanmar & 98 & 98 & 77 \\
\hline Thailand & 37 & 37 & 37 \\
\hline Cambodia & 179 & 179 & 179 \\
\hline Vietnam & 115 & 115 & 59 \\
\hline Lao PDR & 134 & 134 & 134 \\
\hline Bangladesh & 428.9 & 428.9 & 428.9 \\
\hline
\end{tabular}

International Protection

On December 17, 2013, The Multilateral Investment Guarantee Agency (MIGA), the political risk insurance and credit enhancement arm of the World Bank Group, admitted Myanmar as MIGA's 180th member. Myanmar's membership in MIGA means that direct foreign investment into the country is eligible for the agency's investment guarantees. MIGA's guarantees protect investments against the risks of transfer restriction, expropriation, breach of contract, non-honoring of financial obligations, and war and civil disturbance. Investors from Myanmar going into MIGA's other developing member countries may also receive coverage for their investments. 
Stock Exchange Regulatory Quality

The Yangon Stock Exchange (TSX) was inaugurated on Dec. 9, 2015 amid much fanfare but was not open for trading until 25 March 2016. Until the YSX, the only securities market in Myanmar was operated by Myanmar Securities Exchange Centre (MSEC), established in 1995.

In early 2014, over-the-counter shares were sold for K10,000 each. As of October 2016, only three companies- First Myanmar Investment (FMI), Myanmar Thilawa SEZ Holdings Public Limited (MTSH) and Myanmar Citizens Bank (MCB) - were enlisted with a total value of MMK 103 million ( US\$ 96000). Jan. 3 FMI's shares were trading on YSX at 14,000 kyats, MCB's at 9,300 kyats, and MTSH's at 4,500 kyats. A total of 8,148 shares had a market value of 600,630 million kyats. ${ }^{\text {xiv }}$

In the backdrop of general lack of relevant education and technical awareness among the general public, the capital market of Myanmar has a long way to go in positioning itself as an influential catalyst in the country's economy.

\subsection{Trade openness}

Myanmar has industry-specific restrictions on electricity, water and gas distribution, health and education services, transportation, communications, and extraction of natural resources. State monopolies in various key industries exist in the country, which had experimented with its self-concocted version of socialism throughout the mid- $20^{\text {th }}$ century. Various restrictions on private establishments contribute to mismanagement and undue advantage on the part of state-owned enterprises. For instance, the insurance sector, which could be worth as much as $\$ 2.6$ billion by $2030^{\mathrm{xv}}$, is still largely underdeveloped largely due to restrictions faced by private insurers regarding product offerings. Until 2013, the only insurer permitted to operate in the country was state-run Myanma Insurance, which is still excluded from the bindings imposed on private firms.

In 2014, Myanmar prohibited FDI in electric power generation projects of less than $10 \mathrm{MW}$ and required that pharmaceuticals, health and postal services be undertaken through joint ventures with the recommendation of relevant Ministries.

The same year saw a list of 11 items removed from the prohibited list for foreign investors. These items are related to jade and gemstone prospecting, exploration and production, small and medium-scale mineral production, and distribution of newspapers, magazines and journals in Burmese and other national ethnic languages. The import and trade of specific farming and medical 
products have been opened to international business, provided that foreign investors engage in such activities in joint ventures with local firms.

The new mining law passed at the end of 2015 eased complications regarding equity sharing and tenure permits for foreign firms engaged in the exploration and extraction of precious stones, such as the famed jade of Myanmar, and mineral ores such as coal, copper, tin and tungsten.

Myanmar made trading across borders easier by reducing the number of documents required for exports and imports.

In August 2016, Myanmar enacted a national logging ban for one year and a 10-year logging ban in the Pegu Yoma region. Throughout the duration of the ban, Myanmar declared the strategy of using up to three years' worth of available timber from its stockpile to satisfy local and international demands under the management of government-controlled Myanmar Timber Enterprise. Earlier in 2014, Myanmar enacted a ban on raw timber exports in a previous effort to preserve its dwindling forest cover.

Joint ventures between local and foreign companies are not permitted to list on the Yangon Stock Exchange, due to an archaic Myanmar Companies Act dating back to 1914. The colonial-era Act requires companies to seek presidential approval to change their names and court approval to change business objectives. Such draconian regulations are set to be eliminated from the Myanmar business landscape after the adoption of the new Myanmar Companies Law, which is expected to help bring Myanmar's corporate governance framework closer to international standards. Industry experts are also hoping that the new Companies Act will allow foreign investors to buy shares on the Yangon Stock Exchange and thus open up the bourse to the international market.

\subsection{Infrastructure quality}

\section{Energy Infrastructure}

Myanmar's energy infrastructure is still largely underdeveloped. The National Electrification Plan (NEP), an ambitious plan to bring electricity to every community in Myanmar by 2030, requires 7.2 million new household and business connections. Estimated costs for building the grid over the next 15 years will amount to about $\$ 10$ billion. Mobilizing this finance will be one of Myanmar's biggest challenges and will need a financially viable power sector and sound policies. 
Peak consumption in the high summer season was at 2,730 megawatts (MW), though the combined generational capacity of Myanmar's power plants is $2,450 \mathrm{MW}$ as of 2016, leaving a significant shortfall in supply. With demand rising by $300 \mathrm{MW}$ annually, according to Ministry of Energy estimates, stepping up its investment programme will be crucial if Myanmar is to keep ahead of increasing demands on its grid.

FIGURE 2

SOURCES OF ELECTRICITY GENERATION IN MYANMAR (2016)

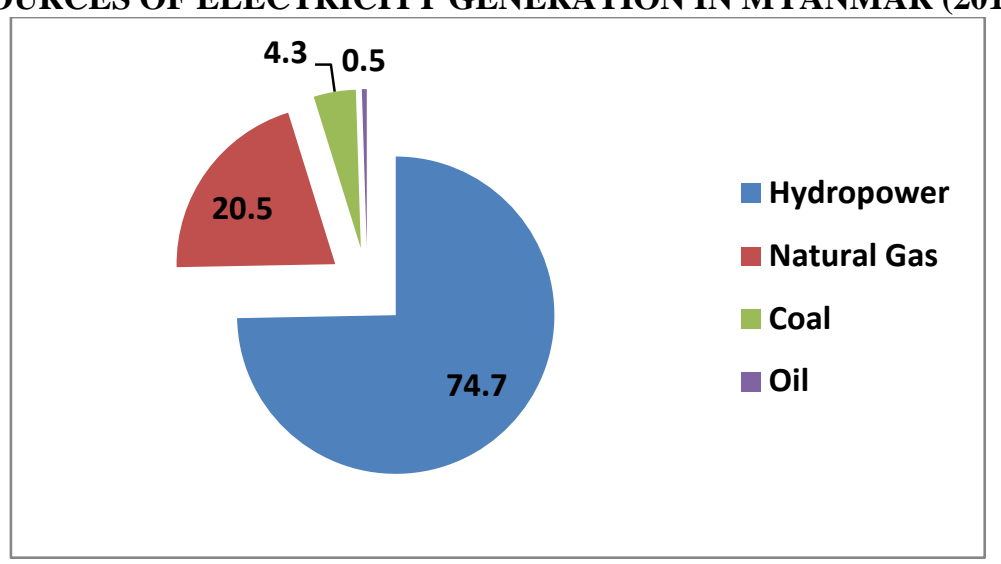

Hydropower generation capacity, which forms two-thirds of the power generation mix, is affected by seasonality and widespread environmental and humanitarian concerns regarding sensitive projects. During the parched seasons of December to March, a significant portion of river flows dry up and power generation capacity plummets. In face of nationwide protests against forced settlement relocations and damage to the environment, construction of the Chinabacked Myitsone Dam - an USD 3.6 billion hydroelectric power development project -was suspended in 2011. Moreover, Myanmar's national electricity infrastructure is old and thus prone to breakdowns. In addition, there are electricity export commitments in place, putting the country in a difficult situation as it simultaneously tries to meet increasing internal demand and to honor export commitments.

\section{Transport Infrastructure}

A host of infrastructure development projects are underway in Myanmar under the national connectivity agenda. In a country which saw little in terms of infrastructure upgrade after independence from colonial rule,- approximately 70 percent of the roads are still unpaved. Though sea trade handles more than 80 
percent of the overall trade, the ports are not able to cater to big vessels above 20,000DWT, requiring manufacturing firms to maintain high inventory.

Only 40 percent of freight shipments in Myanmar arrived according to quality standards (in time and not damaged), compared to 70 percent in Indonesia and 83 percent in Thailand. These severely hamper Myanmar's external competitiveness and its ability to engage in global value chains.

TABLE 2

LOGISTICS PERFORMANCE INDEX (LPI) 2016

\begin{tabular}{|l|l|l|l|}
\hline Country & $\begin{array}{l}\text { World } \\
\text { Ranking }\end{array}$ & $\begin{array}{l}\text { Overall } \\
\text { Score }\end{array}$ & $\begin{array}{l}\text { Infrastructure } \\
\text { Score }\end{array}$ \\
\hline Thailand & 45 & 3.26 & 3.12 \\
\hline Vietnam & 64 & 2.98 & 2.70 \\
\hline Cambodia & 73 & 2.80 & 2.36 \\
\hline Bangladesh & 87 & 2.66 & 2.48 \\
\hline Myanmar & 113 & 2.46 & 2.33 \\
\hline Lao PDR & 152 & 2.07 & 1.76 \\
\hline
\end{tabular}

Special Economic Zones (SEZs)

In Rakhine State, work has begun on the Kyauk Phyu SEZ, and in the south of the country, the Dawei SEZ in the Thanintharyi Region is a. $\$ 8.6$ billion joint venture involving the Thai and Japanese government alongside the Myanmar government. Moreover, the recent approval given to a Chinese company for building a $\$ 3$ billion oil refinery in Dawei SEZ signals China's intent to go for a piece of the Dawei pie. The third SEZ, Thilawa, opened in September 2015. The area is Myanmar's first state-of-the-art industrial zone, fully equipped with utilities such as power and water, and is just $23 \mathrm{~km}$ from Yangon, the country's commercial capital.

In January, the Myanmar government implemented a Special Economic Zone law, which allows for tax exemptions for up to seven years for foreign and local investors, and is expected to allow companies interested in investing in the projects to bypass unnecessary bureaucracy. 
TABLE 3

INDUSTRIES IN THILAWA SEZ

\begin{tabular}{|l|c|}
\hline \multicolumn{1}{|c|}{ Focus of Industry } & $\begin{array}{c}\text { Number } \\
\text { of } \\
\text { Projects }\end{array}$ \\
\hline Export-oriented Manufacturing & 22 \\
\hline Import Substitution & 14 \\
\hline Logistics Services & 16 \\
\hline Construction Support & 8 \\
\hline $\begin{array}{l}\text { Industrial Support ( Human Resource Development, Waste } \\
\text { Management, Packaging) }\end{array}$ & 5 \\
\hline Others & 9 \\
\hline
\end{tabular}

\subsection{Economic and political stability}

Myanmar's strong growth potential is balanced by credit constraints, primarily stemming from its institutional framework. As investor interest increases, Myanmar could face challenges that confront many emerging economies, such as inflation, exchange-rate instability and credit bubbles. shortterm exchange rate pressures, rising inflation. The impact of flooding in JulySeptember 2015 on agriculture contributed to a sharp rise in inflation peaking at $16 \%$ in October 2015. Exports declined by $12 \%$ in nominal terms in the first three quarters of 2015-2016. The institutional capacity and policy responses to deal with these macroeconomic shocks and imbalances have faced some challenges including a sharp increase in monetary financing of the deficit, exacerbating inflationary pressures, and measures to contain the demand for foreign currency and imports. ${ }^{\mathrm{xi}}$

For Myanmar to achieve annual GDP growth of around 8 percent, international experience suggests that it will need to generate total investment equivalent to around 25 to 35 percent of its GDP every year-cumulative investment of approximately $\$ 650$ billion between now and 2030, with $\$ 320$ billion required in infrastructure alone. This investment can be funded through both domestic savings and foreign capital. Based on the experience of benchmark countries, Myanmar's cumulative domestic savings between 2010 and 2030 
could support approximately $\$ 480$ billion of this investment, but only with significant improvements to the banking system.

In the short-term, sound macroeconomic policies and institutions includes balancing a reduction in the government deficit and prudent public debt management for economic stability with an increase in spending for public services and growth

Inflation is projected to increase to $11.3 \%$ in $2015 / 2016$ due to supply pressures caused by the floods and currency depreciation.

In January 2013, Myanmar's arrears to ADB, the World Bank, and Japan International Cooperation Agency (JICA) were cleared with support from the Japanese government. This has reopened the way for Myanmar to access large volumes of highly concessional financing from these development agencies, along with full-scale technical advice and capacity building support.

The democratic government led by NLD, of which Aung San Suu Kyi is the de facto leader, took office on 30 March. In the midst of the optimism surrounding Myanmar and the international community, the vestiges of military dominance still lingers. At both Union and regional levels, at least 25 percent of the seats in Parliament are reserved for Burma Army representatives. The military still controls three ministries: defense, home affairs and border affairs. The General Administration Department, which replaced Burma's civil service during military rule, is still under the authority of the military and controls decision-making down to the smallest administrative unit in all corners of the country.

While most of the economic growth zones situated in central Myanmar enjoy relative stability in terms of political violence, the communal tensions in Rakhine state and the conflict scenarios in the tribal hinterlands to the East present a widely asymmetric picture of peace. ${ }^{\text {xvii }}$

\subsection{Labor quality and costs}

Myanmar's labor force is large and growing - between 2015 and 2025, it will grow 9 percent to 35.1 million, (compared with 4.4 million for Laos and 10.4 million for Cambodia, and 60.7 million for Vietnam for 2025). Whilst there is an excess demand for skilled workers, Myanmar is well placed to grow its low-skill, labor intensive, manufacturing sector, which is vital for job growth. The majority of the workforce in Myanmar are unskilled and suitable for low-value, labor intensive manufacturing industries. 
In terms of labor costs, Myanmar occupies a very advantageous position due to its low wage rate. As seen from the Table below, Myanmar offers very competitive wage rates in comparison to neighboring nations. The prospect of low labor cost is a significant incentive to investors in production facilities for export.

In terms of the quality of highly skilled labor, graduate-level employees are rated highly, in comparison to their ASEAN counterparts, in terms of creativity and adaptability. ${ }^{\text {xviii }}$ However, graduates have room for improvement in their communication skills, teamwork, and analytical and problem-solving skills.

As of May 2016, some 1.4 million migrant workers from Myanmar were employed legally in Thailand ${ }^{\mathrm{xix}}$. Many more unskilled laborers, traveling through the porous border, work as seasonal workers in Thai factories and estates. A significant number of Myanmar citizens work as expatriates in Malaysia, Singapore and other south-east Asian nations. These diasporas form a pool of experienced labor that can be utilized on Myanmar's soil, given that the full potential of the nation's economic development is realized.

FIGURE 3

MINIMUM WAGE RATE COMPARISON ${ }^{\mathrm{xx}}$

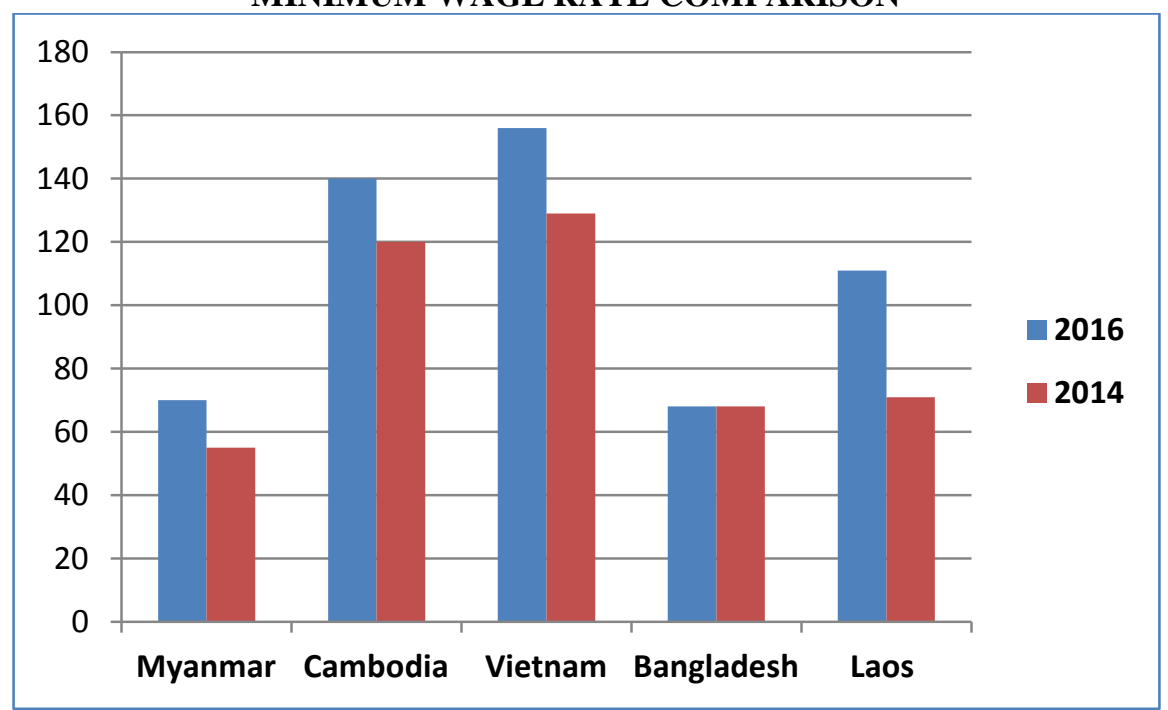




\subsection{Cultural links}

There is evidence that culture has an effect on the choice of foreign investment venture structure ${ }^{\mathrm{xxi}}$ and that besides the economic and comparative advantage theory factors, cultural distance is a critical element that makes foreign investment attractive. Myanmar is a country whose population is grouped into eight major national ethnic races, with 135 different ethnic groups recognized by the government. ${ }^{\text {xii }}$ The current demographic composition of Myanmar, a country influenced by diverse races over the millennia, is primarily of Mongoloid stock. Population genetic analyses revealed that the Myanmar genetic distribution showed a typical Southeast Asian pattern, but also contained Northeast Asian and Indian influences. ${ }^{x i i i}$ The multi-ethnic population and the complex history of Myanmar is reflected in the DNA diversity between and within the various ethnic groups. The Bamars, the major ethnic group of Myanmar who consist of about $68 \%$ of the population, as well as the principal minorities - the Karens, Chins, Kachins and Shans - are ethnically related to the Thais and the Laos ${ }^{\text {xxiv }}$. Ruled by changing kingdoms and dynasties, occupied by the British Empire from 1824 to 1948 , and lying on the trade route between India and China, Myanmar was influenced by a variety of cultures.

The cultural ties and between Myanmar and China date back from the past millennium, when the ethnic Bamars invaded the fertile Irrawaddy river valley from the kingdom of Nanzhao (situated in current-day Yunnan). In 2015, 40.6\% of Myanmar's total global trade was conducted with China ${ }^{\mathrm{xxv}}$, the country which has pumped in the highest amount of foreign investment in the history of Myanmar.

Countries with populations from Mongoloid stock (China, Singapore, Thailand, Hong Kong) occupy the top tier of investors in Myanmar.

It is worthy of note that the countries which Myanmar is courting, after its apparent reintegration in the global economy, are mostly its East Asian compatriots, as demonstrated in lists of current and potential bilateral investment treaty signatories given in Appendix .

Another Asian powerhouse, Japan, has stepped up its involvement in terms of investment, trade and bilateral cooperation with Myanmar. About 4,000 Japanese executives visited Myanmar every month in 2012, the year also marked by Myanmar's first-ever role as the chairman of ASEAN. These en-masse trips made Myanmar the second most popular destination for Japanese business travelers after Thailand. ${ }^{\text {xxvi }}$ 
Among the 80 projects approved from nearly 15 nations and regions in Thilawa SEZ, half are Japanese projects. The East Asian country also has considerable stakes in the SEZ, with JICA providing the majority of funding for constructing the zone. Nearly all projects are either from South-East Asian or East Asian nations, with the USA, Dubai and France having invested in a single project apiece. $^{\text {xxvii }}$

\section{FINDINGS}

A. The macroeconomic indicators of Myanmar, as by the end of 2016, points at the country's emergence as one of the markets with the highest potential for growth in the upcoming decades. In terms of market size and potential, Myanmar is a promising destination for multinational companies as well as for joint venture enterprises. Evidence points at business environment that seems to be more accommodating for investors and entrepreneurs from nations with similar ethnographic backgrounds as the majority of Myanmar's population.

B. Although it remains a challenging destination for investment due to ongoing political uncertainty and a relatively undeveloped legal and regulatory framework, the latest regulations being enforced reflect Myanmar's continued commitment to attracting foreign direct investment.

C. Compared to neighboring economies, Myanmar boasts a large pool of affordable labor. However, Myanmar's workers need to acquire more proficiency and skills in order to compete in the present-day global workforce.

D. The response of the global business community to the advent of the NLDled government has largely been strewn with positivism, with foreign investment gaining record inward flows. Implementing sweeping changes in combating institutional corruption and bringing peace to conflict-ridden border areas, however, is going to be a daunting challenge for the nation's democratic government.

E. ICT infrastructure, RMG manufacturing and tourism are considered as some of the most high-potential sectors for foreign investors in Myanmar. 


\section{RECOMMENDATIONS: PROMISING SECTORS FOR FDI}

\subsection{Information and Communications Technology}

The telecommunications sector of Myanmar was one of the casualties of the inefficiency and incompetence of state-owned enterprises over the decades of international isolation.. Today, two multinational companies - Qatar's Ooredoo and Norway's Telenor- along with state-owned Myanmar Post and Telecommunications (MPT) cater to over 43 million mobile subscribers throughout the length and breadth of the country. MECtel, which started operations in December 2013 and is a subsidiary of military-run Myanmar Economic Corporation, does not hold a Nationwide Telecommunications Licence but had approximately 3.8 million subscribers in mid-2015 under its Mobile Virtual Network Operator licence.

The penetration rate (mobile phones per 100 people) went from less than 10\% in February 2014 to 54.6\% in late March 2015 and reached 63\% in early 2016. Vietnam's telecom major Viettel - the fourth NLT operator in Myanmar is expected to invest up to $\$ 2$ billion over a five-year period as it gears to kickstart operations in early 2017 . Viettel beat six other foreign firms that had shown interest in the bid for the NLT license:- Singapore's Singtel, China Telecom, France's Free, the South African operator MTN, Hong Kong's 1COM, and Beijing Xinwei. As with Telenor's and Ooredoo's license, the new license has been awarded for an initial term of 15 years, extendable for a further decade. Viettel, which operates in 10 countries across Asia, Africa and Americas, will be taking up a 49 percent stake in the consortium with the remaining to be held by local entities.

Alongside falling costs and rapidly increasing access to telecommunications services, internet penetration has increased significantly from less than $10 \%$ in 2014, to 25\% by the end of 2015. A report by the Myanmar Times puts the number of active Facebook users at 10 million. Relatively few number of desktop users and low coverage of fixed internet connections have led to a high demand for mobile data services. Data services provided $40 \%$ of Telenor's revenue in Myanmar for the third quarter of 2016.

4G services have been offered by all of Myanmar's telecom operators, though the technology is still limited to mostly major cities and townships. Ooredoo was the first of Myanmar's operators to begin its 4G rollout, launching services in May in the country's three largest cities.

McKinsey \& Company estimates penetration of mobile voice services to increase from 3 percent in 2011 to 150 percent in 2030. Incidentally, the figures could well be a understatement for the high growth potential in the sector. For 
example, McKinsey \& Company made a conservative estimation that the average monthly revenue per user for mobile voice, data, and SMS in 2030 would be equivalent to $\$ 1.90, \$ 1.40$ and $\$ 0.70$, respectively.

Defying expert estimates, the average total revenue per user for Telenor in Myanmar reached us \$4 in 2016 - an unexpectedly steep increase. While this points out the massive leaps the country is taking in the ICT sector, it could also mean that the growth curve for Myanmar's telecommunications will flatten out earlier than expected.

\subsection{Ready-made Garments Manufacturing}

After Myanmar started pursuing a more open-market approach at the end of the 1980s, the manufacturing sector started developing, albeit at a slow rate. The only opportunity open to the domestic private sector in the following decade was exporting garments to the United States and the European Union under the auspices of the Multi-Fiber Arrangement. These exports operated on a "cut, make and pack" basis. Under this arrangement, the local firms did not have to search for customers abroad, design products, and select imported and domestic raw materials, all of which would have been beyond the limited scope of the private sector in Myanmar at that time. If these merchandising activities had been possible by the local entrepreneurs themselves, it would have been possible for the sector to yield much higher returns in the last decade of the 20th century.

After its reintegration with the mainstream global economy, a resurgent Myanmar has the potential to position itself as a hub of cost-efficient manufacturing. Its growing middle class and youthful population provide ample opportunities for creating a countrywide ecosystem for readymade garments, while its abundant natural resources ensure the availability of raw materials ready for sourcing. Access to the US and the EU markets, once restricted by sanctions but now restored, clearly creates huge opportunities for Myanmar's garments industry. The Economist opines that before Myanmar becomes like Thailand, it will have to become like Bangladesh. The competitive strength of Bangladesh derives from its unlimited availability of unusually cheap but usable labor. Since the competitive strength of a firm or country in the market depends on the specific comparative advantage(s) which its competitors do not have, Myanmar should capitalize on its potential as an outsourced manufacturing destination in the backdrop of rising labor costs in China. Myanmar can provide one of the most cost-efficient manufacturing options in the neighborhood. By safeguarding workers' rights and preventing local production hubs from being branded as "sweatshops", Myanmar can become the regional production hub of the next decade. 


\subsection{Hotel Business and Tourism}

Myanmar's pristine jungles, snow-capped mountains, and sparkling beaches -combined with a rich cultural heritage spanning for millennia - make the country a potential tourist hotspot. However, the country's volatile political situation and administrative mismanagement meant that the potential has thus far remained underexploited. In 2012, tourist arrivals reached 1 million, compared with 3 million in the Lao PDR - a much smaller country — and 22 million in Thailand.

The Ministry of Hotels and Tourism estimated the number of tourist arrivals at over 5 million in the 2016-2017 fiscal year. Average spending by tourists is expected to amount to more than $\$ 3$ billion. In 2015, the average spending by a tourist amounted to nearly $\$ 200$ a day.

Inbound tourism in Myanmar is gradually gaining traction. In 2016, Myanmar had received 2.7 million visitors -of which 800,000 arrivals were by air or ship - till the end of the month of August.

Opaque government regulations regarding the establishment and operations of hotels are a cause of concern for hoteliers and investors in the hospitality industry. Government statistics indicate that there were just under 1,300 hotels throughout the country by the end of 2015. The current minister for Hotels and Tourism, U Ohn Maung, has an entrepreneurial background in the industry - he himself was a successful hotelier prior to his appointment as minister in the newly formed NLD government.

Myanmar's current tourist attractions are primarily historical and archaeological sites - the temples of Bagan, or the ancient kingdom of Mrauk-U, for example. The country with an area of $676,578 \mathrm{~km}^{2}$ is replete with potential sites for sightseeing and adventure tourism. Myanmar's 1930-km long coastline and forest cover of nearly $50 \%$ of the land area provide massive opportunities for a bustling tourism scene.

In sharp contrast with the military regime's approach, present government policy seems congenial to the growth of the hospitality sector, especially the hotel business. The government has cut licensing fees for tour operators, tour guides, hotel and car rental by 50 percent since taking office in April 2016. The central ministry is reportedly planning to grant more licenses for guest houses, tours and tour guides in the near future in order to boost tourism prospects. A well-crafted and comprehensive national tourism strategy, designed with the preservation of local heritage, wildlife populations and ecology in mind, is probably the only way forward for sustainable development of Myanmar's tourism. 


\section{CONCLUSIONS}

Once considered a pariah state because of its military regime, Myanmar has been taking giant strides towards becoming a major player in the context of both the regions of South East Asia and South Asia. Blessed with an abundance of natural resources such as natural gas, gemstones, etc., Myanmar holds immense potential to play the dual role of a regional investment hub and as a connecting node between its peripheral regions.

Myanmar's re-emergence into the global and regional economies has been met with considerable interest from governments and private investors from around the globe. During the decades of Myanmar's isolation, neighbouring countries in developing Asia achieved remarkable economic growth. Developing Asia is now strongly connected to the global economy through regional production networks, which have expanded the frontiers to Myanmar's neighbouring countries such as Thailand, China, and India. In fact, Myanmar has long been the significant missing link in the regional production networks - a gap that may be fulfilled, partially, with the assistance of increased foreign investment inflows.

The beginning of 2017 saw a global economic order on the brink of revolutionary changes, with President-elect Donald J. Trump sending reverberating shockwaves through the world with his rhetoric positioned against free trade. Trump's pledge to pull out of the planned Trans-Pacific Partnership (TPP), a free trade deal with 12 nations on both sides of the Atlantic sent an important signal to Asian economies that they need to embrace regionalism to hedge economies against the impending onslaught of protectionism. As Trump's economic philosophy is being echoed and copied around the world, the return of mercantilism is increasingly turning into a very probable scenario. Myanmar's role looks set to be a crucial piece in the mechanisms of Asia's economy, and indeed, the entire world economic order, in the turbulent days to come. 
APPENDIX

APPENDIX 1: FDI CALCULATION ISSUES

TABLE 4

YEARLY APPROVED AMOUNT OF FOREIGN INVESTMENT BY SECTOR

FOR 2015-2016

\begin{tabular}{|l|l|l|l|}
\hline No. & \multicolumn{1}{|c|}{ Sector } & $\begin{array}{c}\text { Foreign Investment by } \\
\text { Sector (in millions of U.S.D.) }\end{array}$ & \% \\
\hline 1 & Oil and Gas & 4817.8 & 50.81 \\
\hline 2 & Transport \& Communication & 1931 & 20.37 \\
\hline 3 & Manufacturing & 1065 & 11.23 \\
\hline 4 & Real Estate & 728.7 & 7.69 \\
\hline 5 & Power & 360.1 & 3.80 \\
\hline 6 & Hotel and Tourism & 288.4 & 3.04 \\
\hline 7 & Other Services & 235.97 & 2.49 \\
\hline 8 & Mining & 28.9 & 0.30 \\
\hline 9 & Industrial Estate & 10 & 0.11 \\
\hline 10 & Livestock \& Fisheries & 8.3 & 0.09 \\
\hline 11 & Agriculture & 7.18 & 0.08 \\
\hline 12 & Total & 9481.3 & 100 \\
\hline
\end{tabular}


FIGURE 4

DICA VS WORLD INVESTMENT REPORT FDI ESTIMATIONS

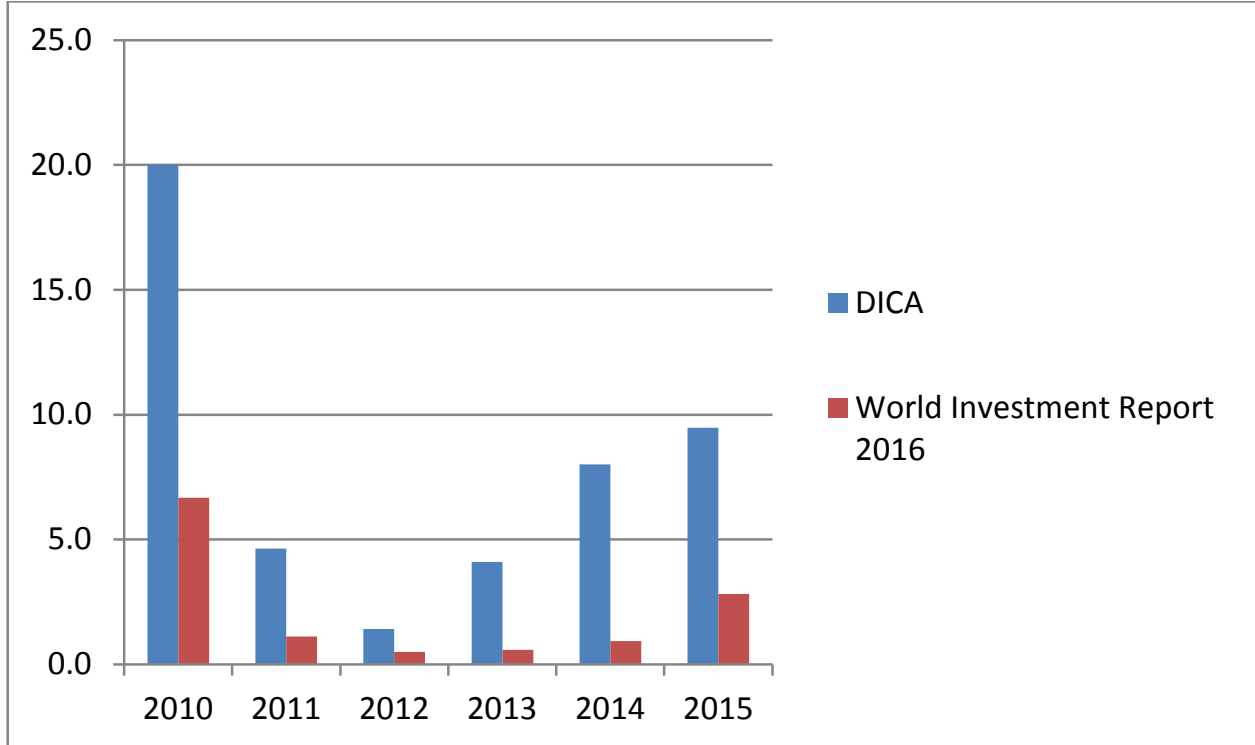

APPENDIX 2

POPULATION DISTRIBUTION IN MYANMAR AND NEIGHBORING COUNTRIES

FIGURE 5

POPULATION BETWEEN THE AGES 0 TO 14 (\% OF TOTAL POPULATION) IN MYANMAR AND NEIGHBORING COUNTRIES

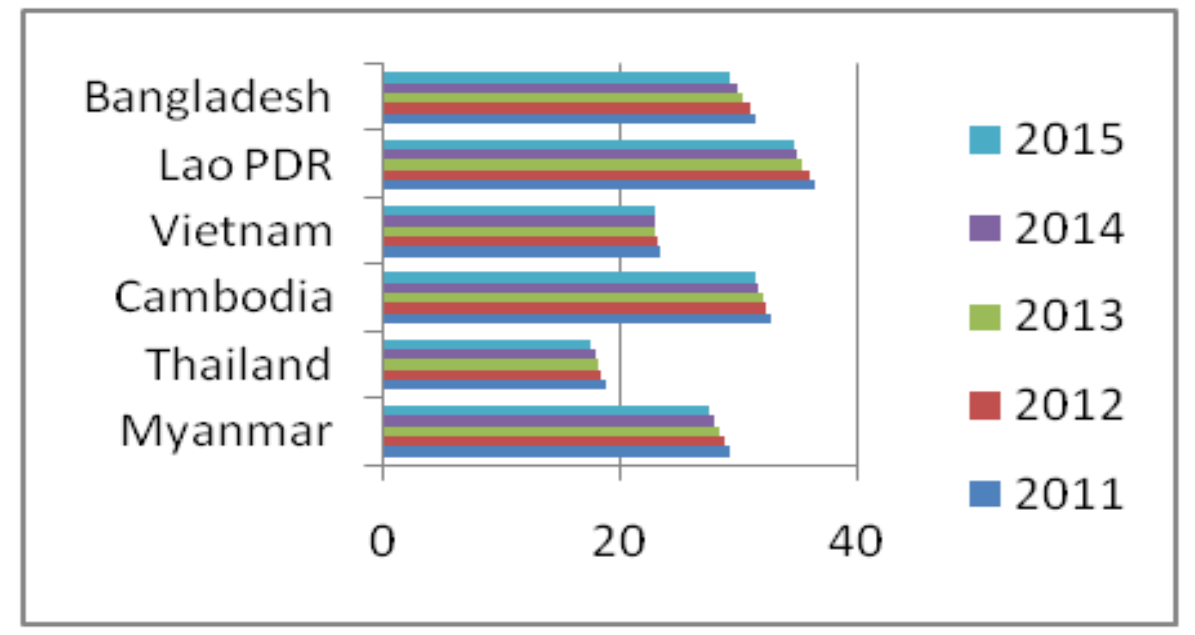


APPENDIX 3

EMPLOYMENT DISCREPANCY AMONG STATES AND REGIONS

TABLE 5

EMPLOYMENT-TO- POPULATION RATIO BETWEEN THE AGES 15-64

\begin{tabular}{|l|l|l|l|}
\hline Region & Total (\%) & Male (\%) & Female (\%) \\
\hline Union & 64.4 & 81.9 & 48.4 \\
\hline Urban & 59.6 & 76.4 & 44.6 \\
\hline Rural & 66.6 & 84.5 & 50.2 \\
\hline Kachin & 64.6 & 82.6 & 44.0 \\
\hline Kayah & 72.3 & 85.7 & 58.9 \\
\hline Kayin & 56.2 & 75.1 & 38.3 \\
\hline Chin & 61.4 & 73.0 & 51.3 \\
\hline Sagaing & 69.7 & 84.5 & 56.8 \\
\hline Tanintharyi & 61.3 & 82.7 & 40.1 \\
\hline Bago & 59.2 & 81.4 & 39.5 \\
\hline Magway & 69.0 & 84.1 & 56.4 \\
\hline Mandalay & 65.7 & 82.8 & 50.7 \\
\hline Mon & 57.2 & 76.2 & 40.3 \\
\hline Rakhine & 52.6 & 75.6 & 53.2 \\
\hline Yangon & 60.5 & 78.3 & \\
\hline Shan & & 86.8 & \\
\hline Ayeyawady & & & \\
\hline Nay Pyi Taw & & & \\
\hline & & & \\
\hline & & & \\
\hline & & & \\
\hline & & & \\
\hline & & & \\
\hline & & & \\
\hline
\end{tabular}




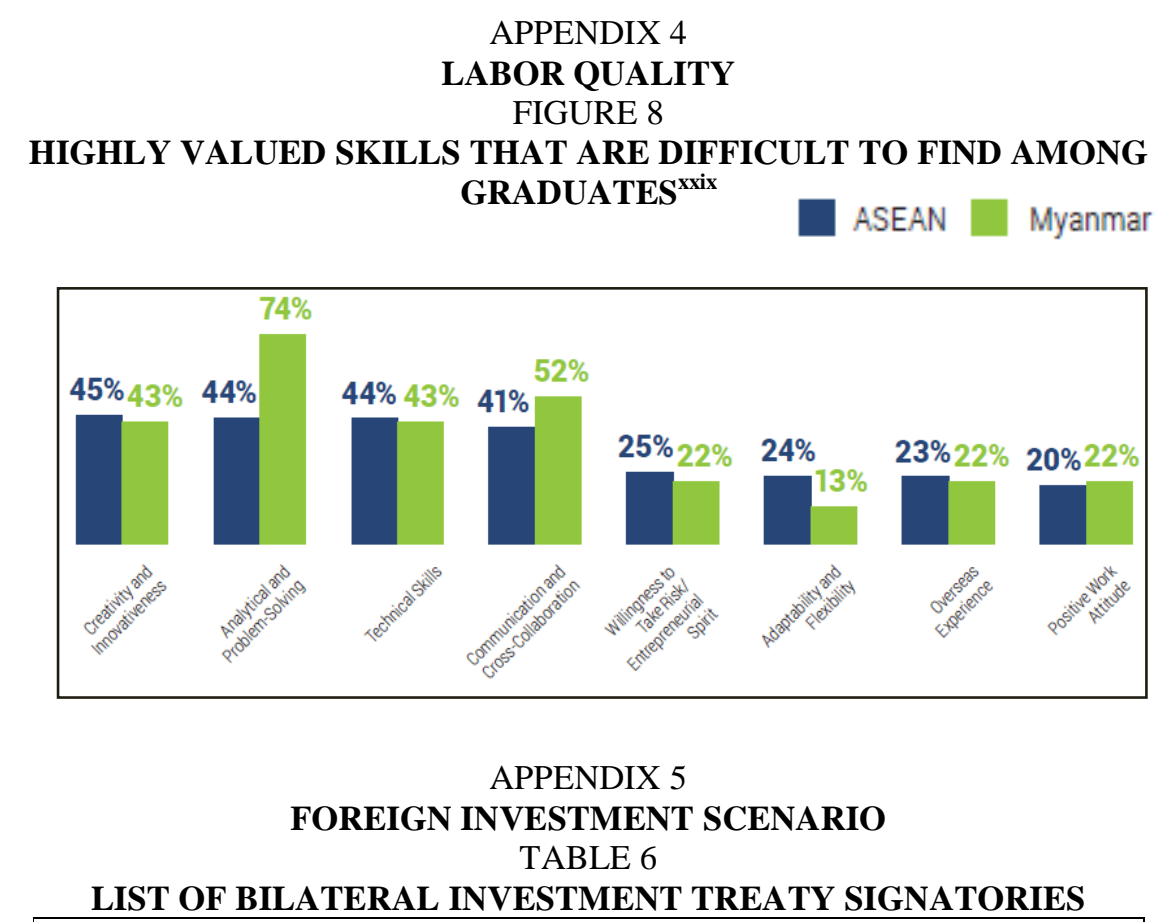

\begin{tabular}{|l|l|l|l|l|l|}
\hline \multicolumn{1}{|l|}{ Countries } \\
\hline Japan & China & Thailand & Lao PDR & Viet Nam & $\begin{array}{l}\text { ROK (South } \\
\text { Korea) }\end{array}$ \\
\hline India & Israel & Philippines & Kuwait & USA & \\
\hline
\end{tabular}


TABLE 7

LIST OF COUNTRIES ONGOING NEGOTIATIONS FOR BILATERAL INVESTMENT TREATY

\begin{tabular}{|c|c|c|c|c|c|}
\hline \multicolumn{6}{|l|}{ Countries } \\
\hline Russia & Bangladesh & Mongolia & Iran & $\begin{array}{l}\text { Hong } \\
\text { Kong }\end{array}$ & $\begin{array}{l}\text { DPRK } \\
\text { (North } \\
\text { Korea) }\end{array}$ \\
\hline $\begin{array}{l}\text { The European } \\
\text { Union }\end{array}$ & Qatar & $\begin{array}{l}\text { Czech } \\
\text { Republic }\end{array}$ & Belarus & Canada & Serbia \\
\hline
\end{tabular}

\section{REFERENCES}

Abdullah, A. (1997). International Trade Implications and Future of ReadyMade Garments Sector of Bangladesh. Journal of Business Administration, IBA, $23,3 \& 4$.

D'Souza, C., Peretiatko, R. (2005). Cultural impact on investment destination choice of US-multinational corporations in Australia. Cross Cultural Management: An International Journal, 12, 3, 14 - 31.

Findlay, R., Park, C., Verbiest, J. (2015). Myanmar: Unlocking the Potential - A Strategy for High, Sustained, and Inclusive Growth. ADB Economics Working Paper Series, 437.

Horberger, K., Battat, J., Kusek, P. (2011). Attracting FDI: How Much Does Investment Climate Matter?. Viewpoint: Public Policy for the Private Sector, No.327. http://www.mmtimes.com/index.php/business/8437-world-bank-revisesgdp-growth-to-6-8.html

Iwamoto, K. (2016, June 25). Thailand pledges to protect rights of Myanmar migrants. Nikkei Asian Review.

McKinsey Global Institute (2013). Myanmar's moment: Unique opportunities, major challenges.

Mon, K. (2017, January 3). First Private Bank to Trade on Yangon Stock Exchange. The Irrawaddy.

Summerer, M., Horst, J., Erhart, G., Weißensteiner, H., Schönherr, S., Pacher, D., ... \& Sanguansermsri, T. (2014, January 28). Large-scale mitochondrial DNA analysis in Southeast Asia reveals evolutionary effects of 
cultural isolation in the multi-ethnic population of Myanmar. BMC evolutionary biology, 14(1), 1 .

Ten, D., May, K. (2013, May 24). Abe Goes to Myanmar as Japan Inc. Eyes Asia's Cheapest Wages. Bloomberg.

Trautwein, C. (2016, April 1), Myanmar mobile leaps along. The Myanmar Times.

\footnotetext{
${ }^{\mathrm{i}}$ The seven factors were identified by the World Bank Group and the selection was based on 30 empirical studies; available online at http://siteresources.worldbank.org/FINANCIALSECTOR/Resources/327-

Attracting-FDI.pdf, accessed on December 20, 2016
}

${ }^{i i}$ Regarding the accuracy of long-term predictions, a pertinent case could be the World Bank's frequent revisions of Myanmar's GDP growth - in 2013, economic forecast for Myanmar was revised up to 6.8 percent from $6.5 \mathrm{pc}$. For the FY2016, the growth forecast was decreased to a comparatively paltry $6.5 \%$ from an initial figure of $8.2 \%$.

Source : http://www.mmtimes.com/index.php/business/8437-world-bankrevises-gdp-growth-to-6-8.html

http://www.mmtimes.com/index.php/business/16833-world-bank-slashesgrowth-forecast.html, accessed on December 21, 2016

iii Source : Global Investment Prospects ASSESSMENT 2016-2018

iv Source : The World Bank's May 2016 edition of the Myanmar Economic Monitor

${ }^{\mathrm{v}}$ Source : Data provided by UNCTAD

${ }^{\text {vi }}$ Calculation Issues: Variance in FDI estimates by different authorities are a cause of concern regarding the accuracy of data. A quick look at the discrepant reporting of total FDI in Myanmar for the 2012 fiscal year is sufficient in illustrating the conundrum. ${ }^{\text {vi }}$ The IMF estimated the amount of inward FDI to be $\$ 2.8$ billion. The ASEAN Secretariat gave a $\$ 1.35$ billion figure, based on DICA estimates, for the same calendar year. UNCTAD, on the other hand, gave a much toned-down figure of $\$ 0.50$ billion - a figure equivalent to only $37 \%$ of that provided by Myanmar government statistics. Further details are given in Appendix 1. 
vii Source : As recorded in a speech by Janet E. Jackson, UNFPA Representative in Myanmar, on 10 July, 2015 at Yangon University

viii Source : The World Factbook, CIA

${ }^{\text {ix }}$ Source : McKinsey Global Institute, 2013

${ }^{\mathrm{x}}$ Source: Doing Business database, accessing on December 27, 2016

${ }^{x i}$ Source : http://www.dica.gov.mm/sites/dica.gov.mm/files/documentfiles/myanmarspecialeconomiczonelaw.pdf, accessed on December 27, 2016

xii Source : www.aseanbriefing.com/news/2016/11/04/analyzing-myanmarsnew-foreign-investment-law.html, accessed on December 27, 2016

xiii Source : World Development Indicators

${ }^{\text {xiv }}$ Source : The Irrawaddy

${ }^{\mathrm{xv}}$ Source : Asia Insurance Review, accessed on December 27, 2017

${ }^{x v i}$ Source : The World Bank, Myanmar Economic Monitor, as of May 2016

xvii Appendix

xviii Appendix

${ }^{x i x}$ Source : Nikkei Asian Review

${ }^{\mathrm{xx}}$ Source : Government Websites, ASEAN Reports

${ }^{x x i}$ Source : Clare D'Souza, Roman Peretiatko (2005

xxii The "Rohingya" ethnic group is not officially recognized by either the central government or the Rakhine state government and "Rohingyas" are not considered as citizens of Myanmar

xxiii Source : Monika Summerer et al (2014)

${ }^{\text {xxiv }}$ Source : Dutt, Ashok's Southeast Asia: A Ten Nation Region

${ }^{x x v}$ Source : European Union: Trade in goods with Myanmar, European

Commission Directorate-General for Trade, as of 21-06-2016

${ }^{x x v i}$ Source : Nikkei Asian Review

xxvii Data collected from "List of Approved Investors" from the official website of the Thilawa SEZ Management Committee http://www.myanmarthilawa.gov.mm/ xxviii Source: The 2014 Myanmar Population and Housing Census Census Report Volume 2-B :Occupation and Industry ${ }^{\text {xxix }}$ Source : ASEAN Business Outlook Survey 2017 by the American Chamber of Commerce and Industries 